\title{
Pelatihan Pengelolaan Kelas Daring Berbasis Aplikasi Google Classroom dan Edpuzzle di SMP PGRI 5 Denpasar Bali
}

\author{
Eka Grana Aristyana Dewi*, I Gst. Agung Pramesti Dwi Putri \\ Sistem Informasi Akuntansi, STMIK Primakara \\ *Corresponding Author. Email: aris@ primakara.ac.id
}

\begin{abstract}
The purpose of this service activity is to improve the ability of teachers at SMP PGRI 5 Denpasar in managing online classes by providing online class management training based on the Google Classroom and Edpuzzle applications. The method of implementing this activity is lecture, practice, and discussion. Lectures were conducted to deliver material on the stages of classroom management using Google Classroom and using videos on Edpuzzle. The participants of this activity were all teachers of SMP PGRI 5 Denpasar totaling 40 people. For online class management, participants were given training in class management and grades, using forums, and making materials and quizzes. For the use of videos as learning materials, participants were training in choosing videos, editing videos, inserting messages and questions as well as multiple choices. The results of this service activity are as many as $72,5 \%$ of participants have been able to manage online classes and integrate with Edpuzzle. Partners have also agreed to use Google Classroom and Edpuzzle for learning for the 2021/2022 academic year.
\end{abstract}

\begin{abstract}
Abstrak: Tujuan dari kegiatan pengabdian ini adalah untuk meningkatkan kemampuan guru di SMP PGRI 5 Denpasar dalam mengelola kelas daring dengan memberikan pelatihan pengelolaan kelas daring berbasis aplikasi Google Classroomm dan Edpuzzle. Metode pelaksanaan kegiatan ini ceramah, praktik, dan diskusi. Ceramah dilakukan untuk menyampaikan materi mengenai tahapan pengelolaan kelas menggunakan Google Classroom dan memanfaatkan video menggunakan Edpuzzle. Peserta dari kegiatan ini adalah seluruh guru SMP PGRI 5 Denpasar yang berjumlah 40 orang. Untuk pengelolaan kelas daring, peserta diberi pelatihan pengaturan kelas dan nilai, pemanfaatan forum, dan membuat materi dan kuis. Untuk pemanfaatan video sebagai materi pembelajaran, peserta diberi pelatihan memilih video, mengedit video, menyisipkan pesan dan pertanyaan serta pilihan ganda. Hasil dari kegiatan pengabdian ini adalah sebanyak $72,5 \%$ peserta telah mampu melakukan pengelolaan kelas daring dan mengintegrasikan dengan Edpuzzle. Pihak mitra juga telah sepakat akan menggunakan Google Classroom dan Edpuzzle untuk pembelajaran tahun akademik 2021/2022.
\end{abstract}

\section{Article History:}

Received: 24-09-2021

Reviewed: 08-10-2021

Accepted: 14-10-2021

Published: 13-11-2021

Key Words:

Training, Google

Classroom,

Edpuzzle, Online

Learning.

\section{Sejarah Artikel:}

Diterima: 24-09-2021

Direview: 08-10-2021

Disetujui: 14-10-2021

Diterbitkan: 13-11-2021

\section{Kata Kunci:}

Pelatihan, Google

Classroom, Edpuzzle,

Pembelajaran Daring.

How to Cite: Dewi, E., \& Putri, I. (2021). Pelatihan Pengelolaan Kelas Daring Berbasis Aplikasi Google Classroom dan Edpuzzle di SMP PGRI 5 Denpasar Bali. Jurnal Pengabdian UNDIKMA, 2(2), 203-210. doi:https://doi.org/10.33394/jpu.v2i2.4244

https://doi.org/10.33394/jpu.v2i2.4244

This is an open-access article under the CC-BY-SA License.

\section{Pendahuluan}

Kegiatan belajar mengajar pada masa pandemi ini dilakukan secara daring sesuai dengan Surat Edaran No. 4 Tahun 2020 Tentang Pelaksanaan Kebijakan Pendidikan Dalam Masa Darurat Penyebaran Coronavirus Disease (Covid-19) yang diterbitkan oleh Menteri Pendidikan dan Kebudayaan (Na'im 2020). Banyak tantangan yang dihadapi para guru dan siswa. Para guru harus mengubah bentuk persiapan mengajar (RPP) dalam kondisi daring. 
Beberapa hal yang harus disesuaikan oleh guru seperti teknik penyampaian materi, teknik penyampaian tugas, teknik penilaian, cara menghidupkan suasana kelas tatap maya, serta cara berkomunikasi dan memberikan konsultasi kepada siswa (Nur Khairiyah Mar'aha, 2020) (Basar, 2021). Penyesuaian ini tentu dibutuhkan agar proses belajar mengajar tetap memiliki kualitas yang sama dengan pembelajaran tatap muka, bahkan bisa lebih meningkat kualitasnya. Peningkatan kualitas pembelajaran sangat penting dilakukan, agar siswa dapat bersaing di era yang serba canggih dan modern ini (Ida, 2020). Peningkatan proses pembelajaran yang berkualitas, diharapkan dapat sejalan dengan pengembangan dan tuntutan kurikulum yang berlaku (Sobri, 2014).

Dalam hal pemanfaatan teknologi untuk proses belajar mengajar, banyak guru yang memanfaatkan fitur WhatsApp Group (WA Group) untuk mengelola kelas daringnya. Penggunaan WA Group ini dirasa mudah dan dapat dimengerti dengan baik oleh siswa. Namun, muncul kendala dalam mengelola semua dokumen digital yang ada pada WA Group. Mulai dari terlalu banyaknya dokumen digital sehingga menyebabkan kebingungan, data siswa yang tercecer, hingga memori telepon genggam yang sangat cepat penuh (Ni'mah, 2021) (Agustini, 2020). Situasi ini juga dialami oleh para guru sekolah menengah pertama di Kota Denpasar, salah satunya adalah SMP PGRI 5 Denpasar. Meskipun sekolah ini terletak di Kota Denpasar, kendala pengelolaan dokumen digital tidak dapat dihindari. Beberapa guru memanfaatkan WA Group untuk penyampaian materi, penugasan, dan berkoordinasi dengan siswa di kelas. Sebagian guru lagi ada yang telah menggunakan Google Classroom untuk pembelajaran. Ketidakseragaman kegiatan pembelajaran daring ini menimbulkan masalah dalam pelaksanaannya. Masalah yang dihadapi berupa pemberian nilai tugas dan perekapan nilai serta pelaporan perkembangan siswa kepada orang tua. Selain itu, guru juga tidak dapat memastikan dengan baik apakah siswa benar-benar telah menonton materi pembelajaran yang disampaikan melalui video. Sehingga guru-guru pun tidak mengetahui dengan baik tingkat pemahaman siswa pada materi yang diberikan.

Untuk membantu para guru menghadapi permasalahan pengorganisasian pembelajaran daring, maka disusunlah suatu pelatihan penggunaan Google Classsroom dan Edpuzzle untuk guru di SMP PGRI 5 Denpasar. Tujuan dari kegiatan pelatihan ini sebagai berikut: 1) Melatih para guru dalam mengelola kelas, materi, dan nilai dalam Google Classroom dan 2) Melatih para guru memanfaatkan Edpuzzle dalam penyampaian materi berbentuk video. Dengan adanya pelatihan ini, diharapkan para guru di SMP PGRI 5 Denpasar dapat mengelola kelas daring dengan lebih efektif dan efisien.

\section{Metode Pengabdian}

Dalam pelatihan ini menggunakan teknik ceramah, praktik, dan diskusi dalam menyampaikan materi.

1) Teknik ceramah untuk menyampaikan fitur-fitur dan langkah-langkah dalam menggunakan Google Classroom dan Edpuzzle, hal ini bertujuan untuk memberikan gambaran kepada para peserta pelatihan terkiat dengan aplikasi yang digunakan.

2) Teknik diskusi dilakukan untuk memberikan kesempatan para peserta pelatihan untuk mengaplikasikan materi yang digunakan sehingga mendapatkan pemahaman terkait materi yang diberikan.

3) Teknik diskusi dilakukan untuk memberikan kesempatan kepada para peserta pelatihan mendapatkan feedback terhadap kendala yang dihadapi saat mengaplikasikan teori yang didapat. 
Untuk melaksanakan langkah-langkah pelatihan tersebut, maka sebelum kegiatan pelatihan dilaksanakan telah melalui beberapa tahap sebagai berikut.

1) Persiapan

Dalam tahapan ini meliputi kegiatan:

a) Berkoordinasi dengan pihak mitra untuk melakukan analisis kebutuhan pelatihan.

b) Menentukan waktu dan tempat pelaksanaan.

c) Menjalin kerja sama dengan pihak mitra.

d) Mempersiapkan alat dan bahan yang dibutuhkan untuk pelaksanaan pelatihan.

2) Pelaksanaan

Dalam tahap pelaksanaan pelatihan, kegiatan ini melibatkan pihak mitra pelatihan. Pelatihan yang diberikan berupa penggunaan Google Classroom dan Edpuzzle untuk pengelolaan kelas pembelajaran daring.

3) Evaluasi dan tindak lanjut

Evaluasi terhadap peningkatan kemampuan mitra untuk pengelolaan kelas daring dilakukan saat sebelum dan sesudah pelatihan. Evaluasi saat sebelum pelatihan berupa pengisian kuesioner terkait aplikasi pembelajaran yang sudah pernah dilakukan. Hasil pengisian kuesioner menunjukkan bahwa seluruh peserta peserta, yaitu sebanyak 40 orang guru sudah mengetahui aplikasi Google Classroom. Namun, hanya 32,5\% guru yang menggunakan Google Classroom secara rutin. Selain itu, para peserta pelatihan belum ada yang mengintegrasikan Google Classroom dengan Edpuzzle. Proses evaluasi sesudah pelatihan dilakukan dengan memberikan penugasan untuk membuat kelas, mengatur kelas, memanfaatkan forum, mengunggah materi dan penugasan, mengatur penilaian, serta memanfaatkan materi video dalam Edpuzzle. Berdasarkan tugas yang dikumpulkan oleh peserta pelatihan, diketahui bahwa 29 orang atau 72,5\% guru telah berhasil memanfaatkan fitur-fitur yang telah diajarkan selama pelatihan untuk kelas yang mereka ampu. Hal ini juga termasuk dalam mengintegrasikan Google Classroom dengan Edpuzzle. Sisanya, sebanyak 11 orang peserta pelatihan masih mengalami kendala dalam mengatur penilaian dan menyisipkan pertanyaan pada video dengan Edpuzzle.

\section{Hasil Pengabdian dan Pembahasan}

Pada tahap persiapan, pihak STMIK Primakara berkunjung ke SMP PGRI 5 Denpasar untuk berdiskusi mengenai kesiapan mitra menerima kunjungan tim dan menemukan kebutuhan pelatihan yang dapat dilakukan untuk pihak mitra serta menentukan waktu pelaksanaan pelatihan. Kegiatan persiapan ini dilakukan selama dua bulan dan pada tanggal 7 Juli 2021 dilaksanakan pelatihan pengelolaan kelas daring menggunakan Google Classroom dan Edpuzzle di Aula SMP PGRI 5 Denpasar yang diikuti oleh seluruh guru di sekolah mitra tersebut.

Pada saat melakukan wawancara kepada pihak mitra, ditemukan permasalahan yang dihadapi oleh guru-guru di SMP PGRI 5 Denpasar adalah pengelolaan dokumen pembelajaran daring dan penyampaian materi berupa video. Untuk membantu menanggulangi situasi tersebut, maka diperlukan pelatihan yang berfokus pada masalah yang dihadapi. Salah satu cara untuk mengelola pembelajaran daring, yaitu menggunakan Google Classroom. Google Classroom merupakan salah satu aplikasi dari Google yang diperuntukkan untuk mengelola pembelajaran daring. Google Classroom tidak hanya dapat memudahkan guru 
dalam mengelola kelas, namun juga dapat memudahkan siswa untuk berkomunikasi dengan guru (Sabran \& Sabara, 2020) (Atikah, Prihatin, hernayati, \& Misbah, 2021).

Fitur-fitur yang disediakan oleh Google Classroom untuk guru antara lain membuat kelas, mengundang siswa untuk bergabung ke dalam kelas, membuat penugasan, membuat kuis, memberikan nilai atas tugas siswa, dan memberikan kembali hasil penilaian kepada siswa. Guru juga akan dimudahkan dengan fitur yang dapat membuat lampiran berupa dokumen, video, tautan, serta dapat pula langsung terhubung ke penyimpanan Google Drive milik guru. Guru pun dapat membuat pengaturan terkait jadwal pengunggahan materi dan batas waktu pengumpulan tugas bagi siswa. Akses ke Google Classroom pun sangat mudah. Google Classroom dapat diakses melalui website dan aplikasi pada telepon genggam.

Google Classroom juga dapat diintegrasikan dengan beberapa platform pembelajaran. Salah satu platform yang dapat diintegrasikan dengan Google Classroom adalah Edpuzzle. Edpuzzle adalah aplikasi pembelajaran berbasis video yang dapat diakses melalui smartphone, laptop, dan PC. Video pembelajaran dapat berupa video yang dibuat sendiri oleh guru ataupun video yang diambil dari Youtube, Crash Course, National Geographic, TED Talks atau Khan Academy. Video yang dimasukkan pada Edpuzzle dapat disunting oleh guru sesuai dengan kebutuhan. Misalnya saja menambahkan catatan dan pertanyaan di sela-sela video. Keunikan dari aplikasi Edpuzzle ini adalah video tidak dapat dilanjutkan jika siswa tidak menjawab terlebih dahulu pertanyaan yang muncul, sehingga mengurangi kemungkinan siswa mempercepat video ke bagian akhir. Untuk dapat menjawab pertanyaan, siswa harus menyaksikan video dengan seksama sebab pertanyaan akan terkait dengan materi yang disajikan pada video. Siswa pun dapat mengulang kembali video yang disajikan sesuai dengan kebutuhan mereka. Pemanfaatan Edpuzzle ini dapat memudahkan guru dalam memantau aktivitas pembelajaran siswa terutama yang memanfaatkan video pembelajaran. Menonton video yang disertai kuis juga dapat menambah minat siswa dalam mempelajari materi yang disajikan. Aktivitas pembelajaran yang dilakukan siswa dapat dimonitoring oleh guru dalam aplikasi Edpuzzle dan Google Classroom dengan mudah (Sirri \& Lestari, 2020).

Maka dari gambaran kondisi sekolah tersebut di atas, pada saat penyelenggaraan pelatihan penggunaaan Google Classroom dan integrasi dengan Edpuzzle dalam mengelola kelas daring berfokus pada hal-hal berikut.

1) Pemanfaatan Google Classroom dalam melakukan pengaturan kelas, pengaturan nilai, pemanfaatan forum, serta membuat materi dan kuis.

2) Pemanfaatan Edpuzzle untuk materi, catatan dan kuis berupa video yang terintegrasi pada Google Classroom.

Dalam pelaksanaan pelatihan, materi dibuka dengan menyampaikan pentingnya keahlian untuk abad ke-21 ( $21^{\text {st }}$ Century Learning Skills) yang dikaitkan dengan kemampuan guru dalam pengelolaan kelas daring. Seluruh peserta pelatihan telah menggunakan beberapa aplikasi daring dalam pengelolaan kelas. Namun intensitas penggunaannya masih cukup rendah. $42,5 \%$ peserta hanya menggunakan aplikasi daring dalam pengelolaan kelasnya sebanyak satu kali dalam seminggu. Penggunaan Google Classroom juga hanya diintegrasikan dengan penggunaan Google Meet. Belum ada peserta pelatihan yang mengintegrasikan Google Classroom dengan Edpuzzle. Hasil pelaksanaan pelatihan ini adalah kelas daring pada Google Classroom untuk kelas pembelajaran di semester ganjil tahun akademik 2021/2022 di SMP PGRI 5 Denpasar. Untuk kelas Google Classroom yang dibuat oleh peserta pelatihan diintegrasikan dengan video yang ada pada Edpuzzle. 72,5\% guru peserta pelatihan telah dapat mengelola kelas dan bahan ajarnya dengan baik. Para guru telah dapat mengatur kelas, mengatur nilai, memanfaatkan forum, membuat materi, kuis dan 
Jurnal Pengabdian UNDIKMA:

Jurnal Hasil Pengabdian \& Pemberdayaan kepada Masyarakat

https://e-journal.undikma.ac.id/index.php/jpu/index

Email: pengabdian@undikma.ac.id
Vol. 2, No. 2 (November 2021)

E-ISSN : 2722-5097

$P g \quad: 203-210$

topik pada Google Classroom. Para guru juga dapat membagikan tautan rekapan nilai belajar siswa kepada orang tua sebagai pelaporan hasil pembelajaran siswa. Untuk aplikasi Edpuzzle, guru telah dapat memanfaatkan video yang dicari pada aplikasi tersebut kemudian dimodifikasi sesuai dengan kebutuhan pembelajaran. Modifikasi yang dilakukan berupa menambahkan catatan dan pertanyaan disela-sela video yang diberikan. Kegiatan pelaksanaan pelatihan dan hasil dari pengelolaan kelas dengan pemanfaatan Google Classroom dan Edpuzzle oleh guru disajikan pada gambar-gambar berikut.

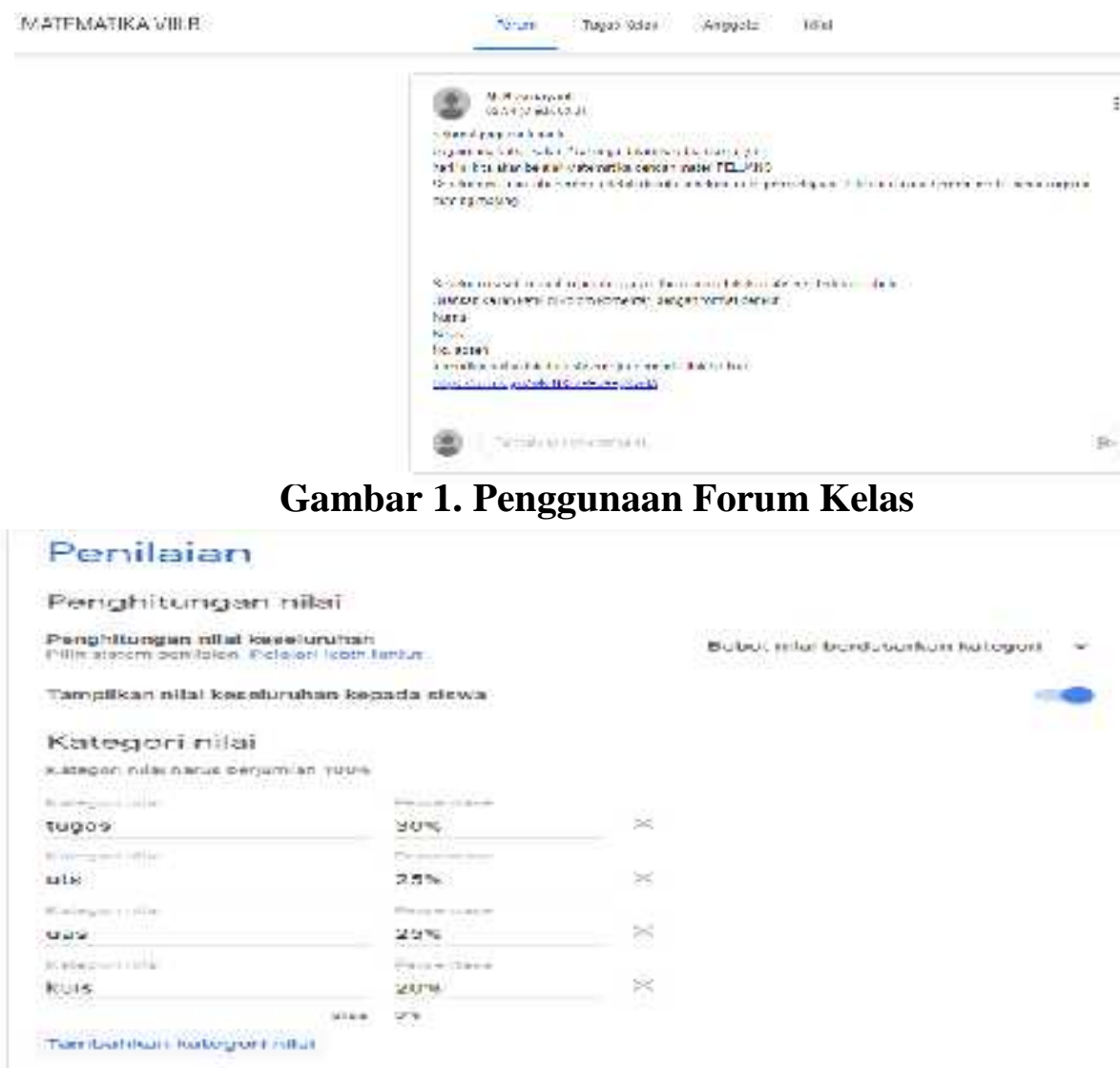

Gambar 2. Mengatur Kategori dan Bobot Nilai

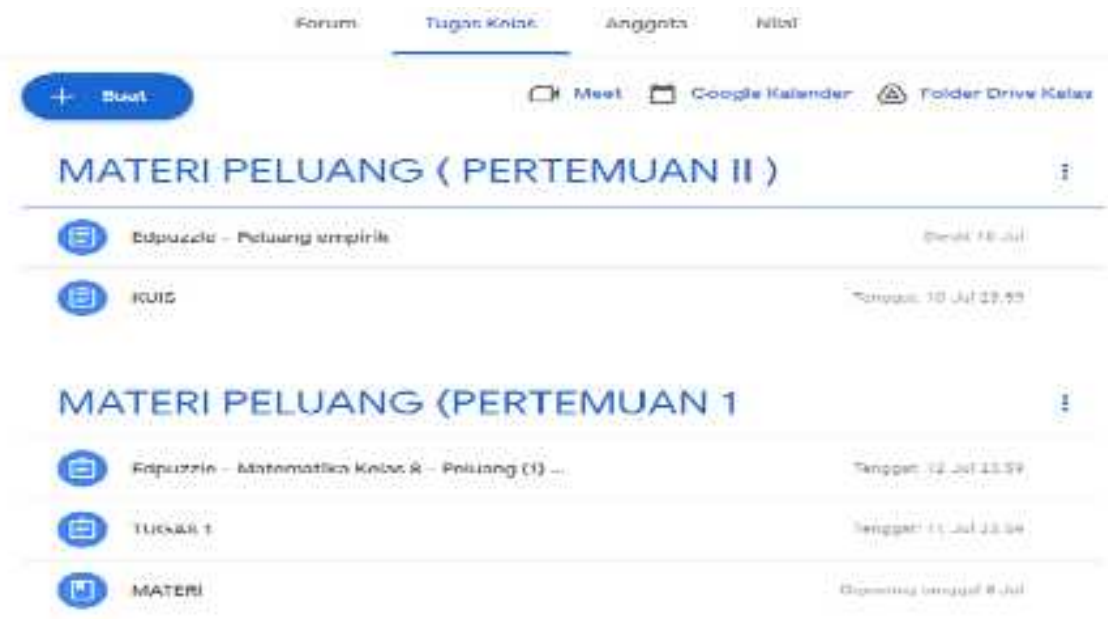

Gambar 3. Menggunggah Kuis, Tugas, dan Materi 
Jurnal Pengabdian UNDIKMA:

Jurnal Hasil Pengabdian \& Pemberdayaan kepada Masyarakat

https://e-journal.undikma.ac.id/index.php/ipu/index

Email: pengabdian@undikma.ac.id
Vol. 2, No. 2 (November 2021)

E-ISSN : 2722-5097

Pg : 203-210

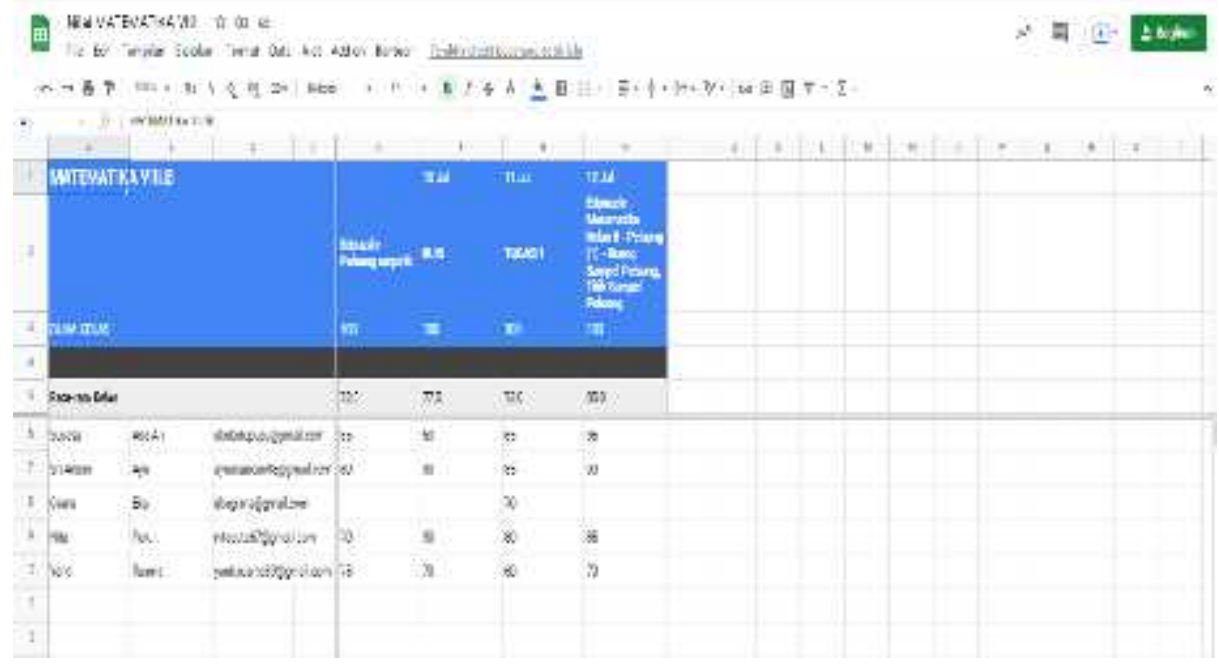

Gambar 4. Mengimpor Rekapan Nilai

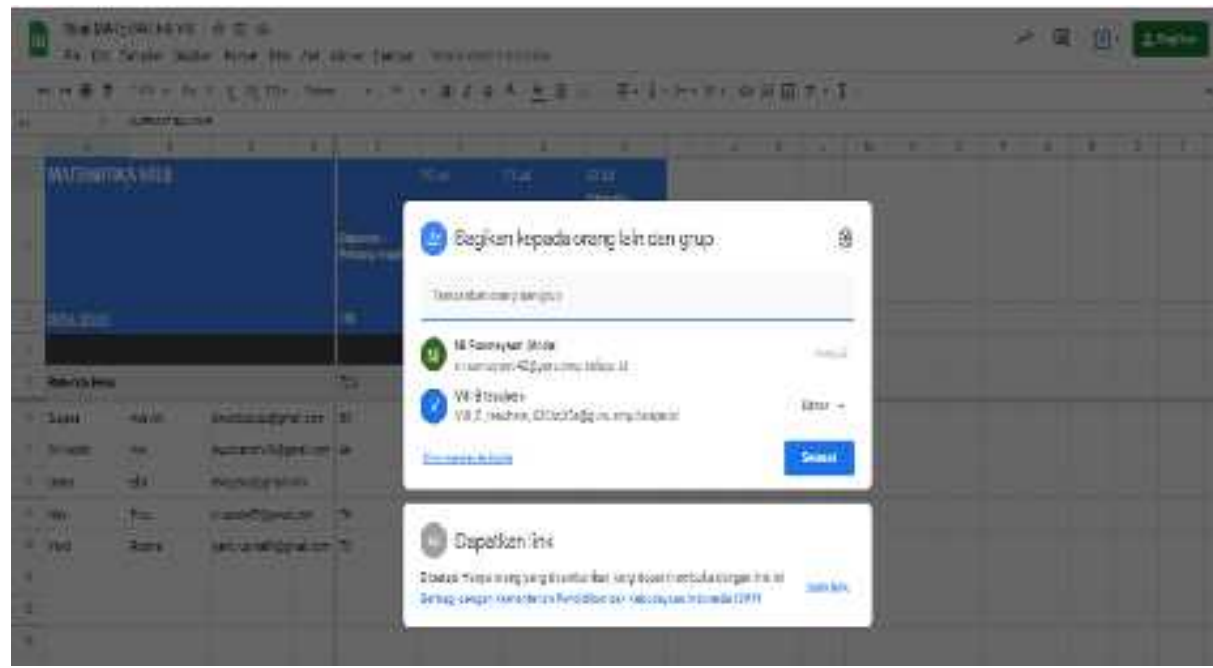

Gambar 5. Membagikan Nilai Kepada Siswa dan Wali

ß3edjuzze

consr: Gostcee Nocrses if 6

Föluang arpiriz:

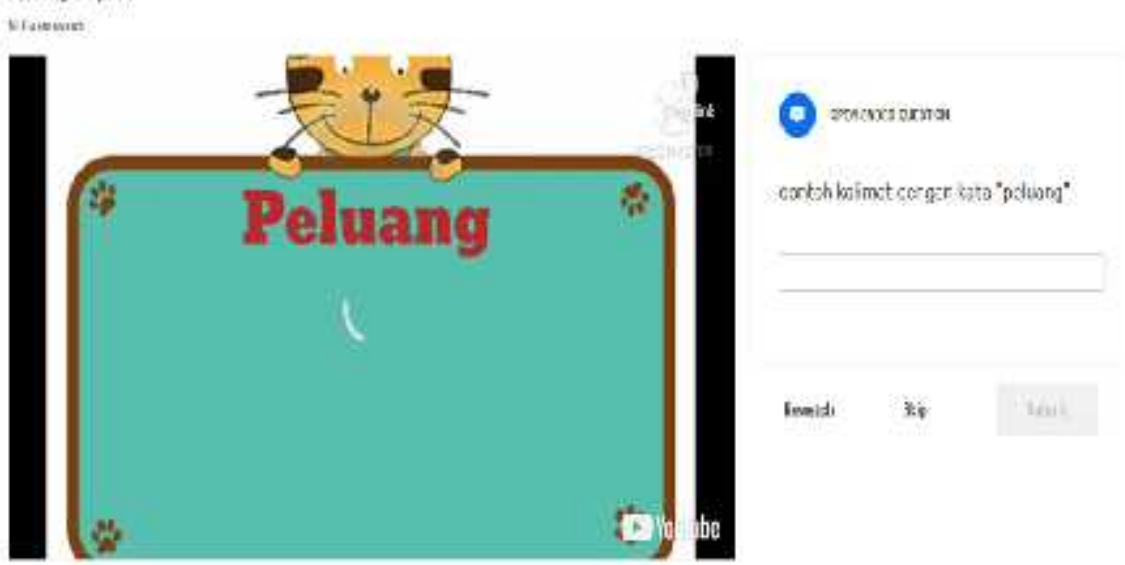

Gambar 6. Penggunaan Edpuzzle Sebagai Media Pembelajaran 


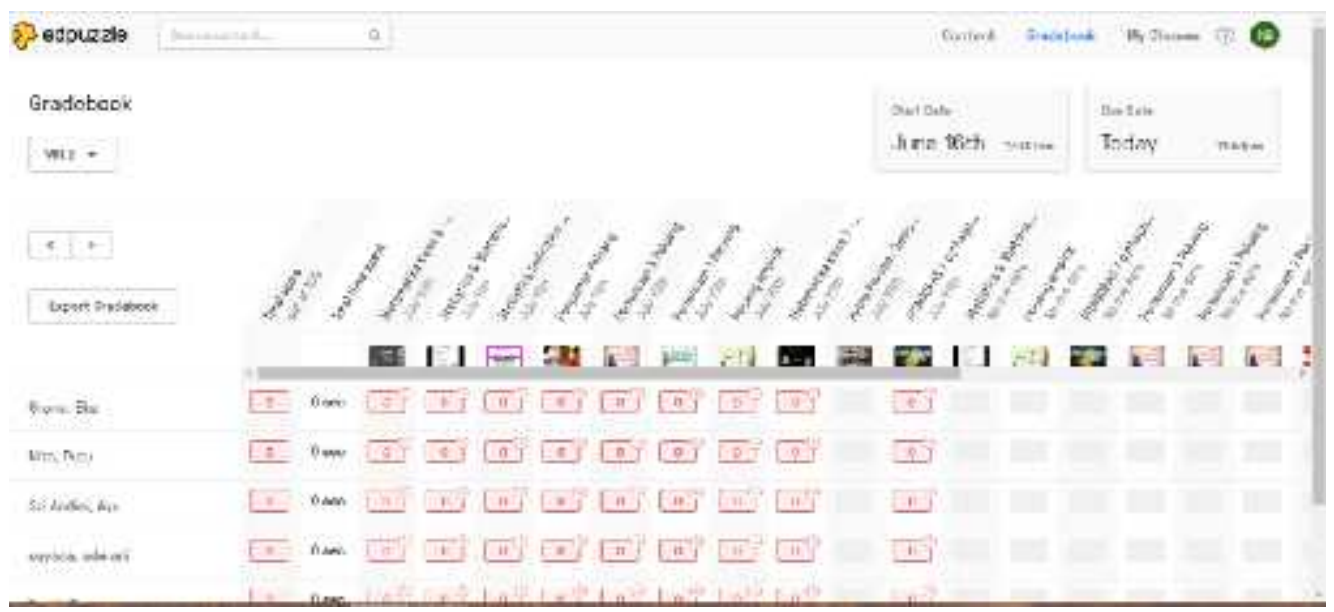

Gambar 7. Memantau Aktivitas Pengerjaan Kuis pada Edpuzzle

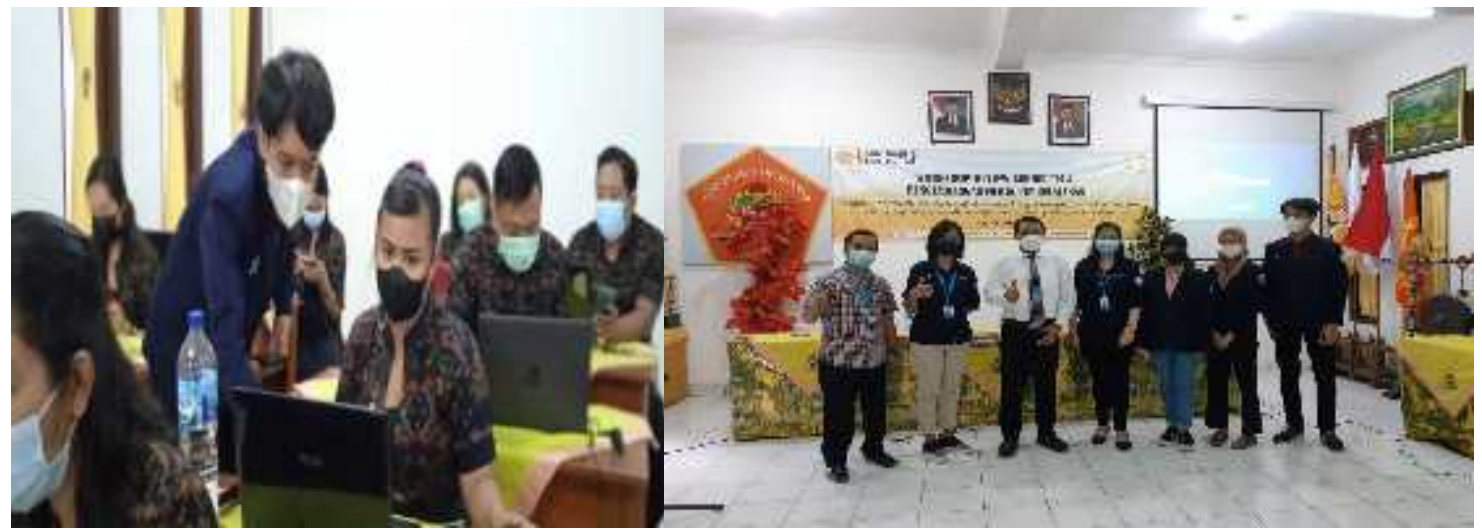

Gambar 8. Pelaksanaan Pelatihan Penggunaan Google Classroom dan Edpuzzle

Tindak lanjut jangka pendek dari kegiatan ini adalah akan direncanakan dan dilakukan pengawasan kepada pihak mitra. Tim akan memonitor kegiatan mitra, pendampingan, dan memberikan arahan serta solusi bagi permasalahan yang ditemukan dalam mengimplementasikan pengelolaan kelas daring. Untuk tindak lanjut jangka panjang, target selanjutnya adalah mengukur efektivitas penggunaan Google Classroom dan Edpuzzle dalam pengelolaan kelas daring.

\section{Kesimpulan}

Kesimpulan yang diperoleh dari kegiatan pengabdian masyarakat ini adalah pelatihan pengelolaan kelas daring dengan menggunakan Google Classroom dan Edpuzzle sangat bermanfaat bagi pihak mitra dalam mengelola pembelajaran secara daring mulai dari pemberian materi, latihan, hingga mengembalikan hasil kerja siswa, memanfaatkan video pembelajaran sebagai materi pembelajaran untuk meningkatkan efektivitas pembelajaran.

\section{Saran}

Adapaun saran yang dapat disampaikan berdasarkan hasil kegiatan ini yakni perlu pembinaan dan pelatihan dalam pengelolaan kelas daring sehingga tujuan pembelajaran dapat tercapai serta kelas daring menjadi lebih menyenangkan. 


\section{Daftar Pustaka}

Agustini, N. P. (2020). Penggunaan Media Sosial Whatsapp Pada Pembelajaran Agama Hindu Untuk Di Masa Pandemi. Jurnal Widya Sastra Pendidikan Agama Hindu, 6772.

Atikah, R., Prihatin, R. T., hernayati, H., \& Misbah, J. (2021). Pemanfaatan Google Classroom Sebagai Media Pembelajaran Di Masa Pandemi Covid-19. Jurnal PETIK, 7-18.

Basar, A. M. (2021). Problematika Pembelajaran Jarak Jauh Pada Masa Pandemi Covid-19. Edunesia : Jurnal Ilmiah Pendidikan, 208-218.

Ida Bagus Nyoman Mantra, I. A. (2020). Peningkatan Kompetensi Mengajar Secara Online Bagi Para Guru Selama Pandemi Virus Corona. Jurnal Abdi Dharma Masyarakat, 1220.

Na'im, Ainun. (2020). Kemdikbud.go.id. Retrieved from kemdikbud.go.id: https://www.kemdikbud.go.id/main/files/download/27bdb5850ac3939.

Ni'mah, S. F. (2021). Penggunaan Whatsapp Group dalam Meningkatkan Motivasi Belajar Siswa pada Mata Pelajaran IPS Kelas VIII di MTsN 1 Bojonegoro. Malang: Universitas Islam Negeri Maulana Malik Ibrahim .

Nur Khairiyah Mar'aha, A. R. (2020). Perubahan Proses Pembelajaran Daring Pada Siswa Sekolah Dasar di Tengah Pandemi Covid-19. SEMINAR NASIONAL PASCASARJANA 2020 (pp. 445-452). Semarang: Universitas Negeri Semarang.

Sabran, \& Sabara, E. (2020). Keefektifan Google Classroom sebagai Media Pembelajaran. "Diseminasi Hasil Penelitian melalui Optimalisasi Sinta dan Hak Kekayaan Intelektual" (pp. 122-125). Makassar: Lembaga Penelitian Universitas Negeri Makassar.

Sirri, E. L., \& Lestari, P. (2020). Implementasi Edpuzzle Berbantuan Whatsapp Group sebagai Alternatif Pembelajaran Daring pada Era Pandemi. Jurnal Pendidikan Matematika Indonesia, 67-72.

Sobri, M. (2014). Efektivitas Pembelajaran Media E-Learning Berbasis Web dan Konvensional Terhadap Tingkat Keberhasilan Belajar Mahasiswa (Studi Kasus Mahasiswa Fakultas Ekonomi Universitas Bina Darma Palembang). SNASTIKOM, 13. 